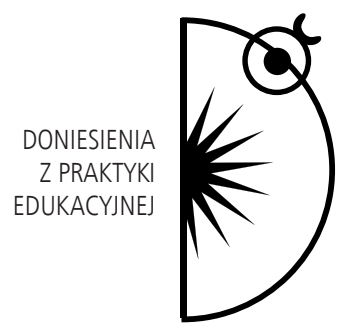

Piotr Kwiatek

Peter P. Bajer

\title{
Aplikacja psychologii pozytywnej w edukacji na przykładzie doświadczenia Geelong Grammar School (Australia)
}

DOI: http://dx.doi.org/10.12775/PBE.2013.022

\section{Wprowadzenie}

Postulat „pozytywnej edukacji” aktualnie formułowany przez założyciela nurtu pozytywnej psychologii Seligmana i jego współpracowników (Seligman, 2008, 2011; Seligman i in., 2009) nie jest czymś nowym w historii długoletniej pedagogiki. Wystarczy choćby wspomnieć francuskiego myśliciela Rousseau, który w XVIII wieku głosił tzw. koncepcję naturalnego wychowania (Rousseau, 1979), lub amerykańskiego socjologa i pedagoga Dewey'a który wskazywał, że podstawowym zadaniem szkoły jest pobudzanie wrodzonych zdolności dzieci, zainteresowań, wzbogacanie doświadczeń, samodzielna praca, natomiast wiedzę zdobywa się niejako przy okazji (Dewey, 1897). Ważnym elementem wzrostu jest doświadczenie (learning by doing), uczenie się przez rozwiązywanie problemów w konkretnym kontekście społeczno-kulturowym, w którym człowiek żyje (Dewey, 1938). Innym przykładem ,pozytywnego” podejścia do możliwości dziecka jest koncepcja włoskiej pedagog Montessori. W jednej ze swoich pozycji twierdzi, że nie można stworzyć geniusza, natomiast można dać każdej osobie szansę spełnienia swojego ludzkiego potencjału (Montesso- 
ri, 1949). Oczywiście są to tylko wybrane i nieliczne przykłady pozytywnego podejścia do naturalnych możliwości dziecka w procesie wychowania. Co zatem nowego wnosi nurt psychologii pozytywnej w edukację? Celem niniejszego artykułu będzie prezentacja i ocena doświadczenia edukacji pozytywnej na przykładzie GGS w Australii, gdzie program jest wdrażany i realizowany od kilku lat.

\section{Potrzeba „psychologii balansu"}

Dziś przeciętny człowiek żyjący w krajach rozwiniętych cieszy się jak nigdy dotąd dobrymi warunkami życia (Harris, 2008; Myers, 2000). Jeszcze kilkanaście lat temu posiadanie samochodu, komputera, telewizora, pralki czy telefonu komórkowego było oznaką luksusu i bogactwa. Wraz z rozwojem medycyny i technologii dziś można leczyć choroby, na które jeszcze kilkadziesiąt lat temu umierało tysiące ludzi. Progres i powszechność odnosi się również do edukacji, coraz więcej ludzi potrafi czytać i pisać, co jeszcze niedawno wcale nie było takie oczywiste. Autor książki The Happiness Trap: How to stop struggling and start living zauważa, że dzisiejsza średnia klasa żyje lepiej niż nie tak dawno temu królowie, a mimo to ludzie nie wydają się bardziej szczęśliwi (Harris, 2008). W świetle tych licznych i pozytywnych przemian aż dziwi fakt, że współczesny człowiek wcale nie wydaje się szczęśliwszy od tego, który żył 50 czy 100 lat temu. Paradoksalnie chorujemy częściej i mamy coraz poważniejsze problemy związane ze zdrowiem psychicznym oraz funkcjonowaniem w społeczeństwie. Międzynarodowa Organizacja Zdrowia (WHO) alarmuje, iż depresja, aktualnie znajdująca się na czwartym miejscu w rankingu chorób, w roku 2020 r. obejmie swoim zasięgiem 30\% populacji, co spowoduje, że przesunie się na drugie miejsce w rankingu wyzwań zdrowotnych (Sharma i in., 2011, s. 108). Rodzi się więc pytanie, dlaczego pomimo tak szybkiego tempa wzrostu gospodarczego, lepszej edukacji, większych wygód życiowych, nie wzrasta poczucie szczęścia i zadowolenia z życia? Czym jest dobrostan psychiczny człowieka? Czy można go zdobyć na stałe lub świadomie do niego się zbliżać? To tylko niektóre pytania, przed którymi stają współcześni badacze jakości życia.

Seligman i Ciskszentmihalyi - założyciele nurtu psychologii pozytywnej wskazują, że psychologia jako nauka po II wojnie światowej zbytnio skupiła się na negatywnych aspektach życia, takich jak patologia, przemoc, agresja, kryzys, depresja, tracąc przy tym kontakt z tym, co jest pozytywne i dobre w życiu człowieka i społeczeństwa, jak np. radość, szczęście, zadowolenie, wdzięczność, nadzieja, harmonia, pasja (Seligman, Ciskszentmihalyi, 2000). Seligman 
twierdzi, że był czas, kiedy „na każde sto artykułów o smutku przypadał tylko jeden o szczęściu” (Seligman, 2005, s. 23). Ogólnym celem psychologii pozytywnej jest więc przywrócenie nauce utraconego balansu (Seligman i in., 2006), a także zajęcie praktycznej postawy względem współczesnych wyzwań społecznych związanych z jakością życia. Nie chodzi tutaj przy tym o porady, jak szybko osiągnąć szczęście, chwilowo poprawić nastrój, czy o pozytywizowanie doświadczeń negatywnych, ale raczej o wiedzę opartą na metodologicznych badaniach (Gable, Haidt, 2005). Psychologia pozytywna jest wiedzą stosowaną nie tylko w edukacji, ale również i w ekonomii, psychoterapii, pracy, w kontekście rodzinnym, a ostatnio nawet w wojsku (Seligman, 2011; Linley, Joseph, 2004; Terjesen i in., 2004; Duckworth i in., 2005; Cameron, 2008; Conoley, Conoley, 2009; Magyar-Moe, 2009; Donaldson, Ko, 2010). Jest ona adresowana do wszystkich, bez względu na wiek, profesję zawodową czy poglądy polityczno-religijne. Pragnie wzmacniać dobro w życiu przeciętnego człowieka (Sheldon, King, 2001). Można powiedzieć, że szczególnie jest ona adresowana do współczesnego odbiorcy, którego Gulla i Tucholska charakteryzują w następujący sposób: „Człowiek, który zapomniał, jak cieszyć się prostymi zmysłowymi przyjemnościami, zatracił kontakt z własną naturą, z innymi ludźmi i z przyrodą. Poświęca on czas na pracę lub bierny odpoczynek, żyje w pośpiechu, w pogoni za sukcesem, a gdy osiągnie sukces, nie potrafi się nim cieszyć. W nadmiarze dóbr materialnych żyje »w nędzy duchowej«" (Gulla, Tucholska, 2007, s. 134).

\section{Potrzeba „edukacji pozytywnej"}

W świetle powyższej diagnozy kondycji człowieka oraz wyzwań społecznych warto zastanowić się, czy dzisiejsze systemy edukacyjne zmierzają w odpowiednim kierunku, albo inaczej mówiąc, czy odpowiadają one na współczesne oczekiwania. „Każdy system edukacyjny wyrasta z założeń charakterystycznych dla danej kultury, w określonym czasie historycznym. Ucząc nasze dzieci, myślimy o tym, jakich chcemy mieć dorosłych za kilkanaście lat. A wyobrażenie na temat człowieka budujemy w oparciu o dominujące wartości charakterystyczne dla naszej kultury" (Kulik, 2010, s. 5).

Seligman wyjaśniania, czym jest edukacja pozytywna, stawiając następujące pytania - pierwsze skierowane do rodziców: „w kilku słowach powiedź, czego pragnąłbyś najbardziej dla swoich dzieci”, i drugie: ,jak myślisz, co aktualnie szkoła daje twoim dzieciom?" (Seligman i in., 2009, s. 293). Okazuje się, że odpowiedzi na te dwa pytania były rozbieżne. Na pierwsze pytanie rodzice 
odpowiadali następująco: „szczęścia, pewności siebie, zadowolenia, równowagi, dobrych rzeczy, uprzejmości, zdrowia, satysfakcji z życia”. W skrócie - to wszystko, z czym jest związany dobrostan (szczęście). Na drugie pytanie padały następujące odpowiedzi: „osiągnięcia, zdolność myślenia, sukces, literatura, matematyka, dyscyplina”. W skrócie - to wszystko, co jest związane z wiedzą i osiągnięciami (Seligman i in., 2009, s. 293).

Edukacja pozytywna jest zatem zastosowaniem wiedzy teoretycznej w środowisku szkolnym (szeroko rozumianym), w którym uwzględnia się nie tylko tradycyjne cele i metody, ale również to wszystko, co pomaga uczniowi wzrastać w dobrostanie (Seligman i in., 2009). Należy podkreślić, że edukacja pozytywna nie wypiera istniejących modeli edukacyjnych skoncentrowanych na umiejętnościach, przekazywaniu wiedzy, ale poszerza je o wiedzę i doświadczenia związane z dobrostanem i jakością życia. Opiera się to na przesłankach potwierdzonych przez badania, mówiących, że dobrostan ludzki, podobnie jak właściwości fizyczne czy umysłowe człowieka, można aktywnie rozwijać oraz kształtować (Peterson, Seligman, 2004; Czapiński, 2004; Lyubomirsky, 2008; Magyar-Moe, 2009; Seligman, 2011). Edukacja pozytywna może więc przynieść liczne korzyści dla ucznia i osób zaangażowanych w proces ich kształtowania. Po pierwsze, promując talenty, zdolności i umiejętności ucznia, wzmacnia się nie tylko jego indywidualne strony osobowości, ale pozytywnie oddziałuje się na relacje między ludzkie oraz szeroko rozumiany wymiar społeczny życia. Po drugie, rozwijając mocne strony charakteru młodego człowieka, pośrednio wzmacnia się faktory obronne chroniące przed zaburzeniami osobowości czy poważnymi chorobami psychicznymi. W końcu dobrostan ucznia pozytywnie skorelowany jest $\mathrm{z}$ zaangażowaniem $\mathrm{w}$ naukę (postęp dydaktyczny), inaczej mówiąc, rozwijając dobrostan ludzki ucznia, wzmacnia się tzw. tradycyjne cele edukacyjne: zdobywanie wiedzy i przystosowanie do środowiska (Seligman i in., 2009).

Podczas pierwszej konferencji naukowej zorganizowanej przez The International Positive Psychology Association - IPPA (Międzynarodowe Stowarzyszenie Psychologii Pozytywnej) w czerwcu 2009 r. założyciel nurtu wyraził pragnienie, aby w $2051 \mathrm{r}$. 51\% populacji na świecie dobrze prosperowało - flourishing (za: Sander, 2011, s. 309). Ten dalekosiężny i optymistyczny cel Seligmana byłby tylko mglistym marzeniem, gdyby nie fakt, że psychologia pozytywna rozprzestrzenia się po całym świecie w bardzo szybkim tempie (Kwiatek, 2011, 2012). W latach 2005-2006 na Uniwersytecie Harwarda - jednym z najbardziej prestiżowych ośrodków akademickim na całym świecie - zajęcia z psychologii pozytywnej prowadzone przez Tala Ben-Shahara gromadziły 855 studentów, 
przekraczając $\mathrm{w}$ ten sposób rekordową liczbę studentów przychodzących na zajęciach z ekonomii (688 studentów), które cieszyły się wcześniej największą popularnością (Watson, 2010). Pokazuje to nie tylko wielką atrakcyjność przedmiotu samego w sobie, ale również współczesną potrzebę rozumienia, czym jest dobrostan (well-being). Dziś psychologia pozytywna jest wykładana na wielu uniwersytetach na całym świecie, m.in. w Australii, Wielkiej Brytanii, Kanadzie, Japonii, Chinach, Meksyku. W samych tylko Stanach Zjednoczonych jest ona obecna w ponad 100 różnych ośrodkach akademickich (McHenr, 2009). Najbardziej znane kursy prowadzone są w Filadelfii (Pensylwania) Master of Applied Positive Psychology (MAPP), gdzie pracuje Seligman, oraz w Cleveland (Ohio), gdzie za program doktorancki odpowiada Csikszentmihalyi (Seligman, 2011).

\section{Aplikacja psychologii pozytywnej w edukacji Geelong Grammar School (GGS) - geneza doświadczenia}

Geelong Grammar School jest największą koedukacyjną szkołą z internatem w Australii. Założona w 1855 r., GGS kształci około 1570 dziewcząt i chłopców na czterech kampusach (Bostock - od zerówki do klasy IV; Toorak - do klasy V; Timbertop - klasy IX, oraz Corio, gdzie w Middle School uczą się dzieci od klasy V do VIII, i Senior School - od klasy X do XII). GGS przyciąga uczniów z odległych krańców Wiktorii, innych stanów Australii oraz z zagranicy. Oparta na podstawach chrześcijańskich, a dokładniej na doktrynie anglikańskiej, szkoła szczyci się bogatym programem zapewniającym wszechstronne wykształcenie. Szczególnie ważnym elementem edukacji w GGS jest internat (boarding). Większość uczniów rozpoczyna kontakt z internatem w klasie VII, to jest na początku gimnazjum (Middle School). Uczniowie mieszkający daleko od szkoły przyjmowani są jako tzw. full-time boarders, czyli uczniowie na stałe mieszkający na terenie GGS podczas roku szkolnego. Do szkoły uczęszczają także uczniowie, którzy mieszkają niedaleko od danego kampusu, a z racji tego nie potrzebują stałego zakwaterowania w GGS. Uczniowie ci, tzw. day boarders, w ciągu tygodnia pozostają w szkole od 8.30 rano do 16.00 - dotyczy to gimnazjalistów. Licealiści (Senior School) przebywają w internacie dziennym od 8.30 rano do 20.30. Wszystkim uczniom zapewniony jest nie tylko przekaz wiedzy czy umiejętności w formie lekcji, zajęć pozaszkolnych czy treningów sportowych, ale również najróżniejsze formy opieki wychowawczej, u podłoża których leży troska o ich dobrostan. Ukształtowany w ciągu ostatnich 150 lat model szkoły z internatem stawia sobie za cel stworzenie specyficznego śro- 
dowiska opartego na silnych relacjach pomiędzy uczniami oraz uczniami i ich wychowawcami, w którym następuje przemiana młodego człowieka w decydujących latach jego rozwoju. W założeniu taka wszechstronna edukacja ma za zadanie wychowanie uczniów na odpowiedzialnych, zaangażowanych i opiekuńczych obywateli.

Wysiłki GGS zmierzające do zmiany podejścia do nauczania i uczenia się oraz rozwoju i formacji ludzkiego dobrostanu spowodowały zainteresowanie szkoły psychologią pozytywną jako strategią rozwojową pomocną w procesie edukacyjnym. W 2005 r. uwagę dyrekcji GGS zwróciły prace prowadzone przez zespół badawczy Seligmana z Centrum Psychologii Pozytywnej na Uniwersytecie w Pensylwanii (Penn) w USA, mające na celu nauczanie dobrostanu. Po przeanalizowaniu skonstruowanych przez zespół Seligmana programów nauczania (Penn Resiliency Program [PRP] i Strath Haven Positive Psychology Curriculum) oraz rozmowach z koordynatorem projektu GGS zdecydowała się na podjęcie działań w celu włączenia tego typu nauczania do wszystkich aspektów własnego programu edukacyjnego. Był to pionierski krok, albowiem do tego czasu szkolenie technik pozytywnego nauczania wśród nauczycieli amerykańskich i brytyjskich odbywało się tylko w warunkach kontrolowanych i obejmowało wybrane grupy uczniów. W celu stworzenia podstaw do nauczania dobrostanu na wszystkich kampusach i na każdym poziomie szkoły oraz wdrożenia tego do wszystkich aspektów życia szkolnego GGS zdecydowała się na jednorazowe przeszkolenie około stu zatrudnionych w szkole nauczycieli i wychowawców.

W styczniu 2008 r. szkoła zaprosiła Seligmana i jego piętnastoosobowy zespół z Penn do poprowadzenia specjalnie ułożonego dla potrzeb szkoły kursu. Celem tego 9-dniowego szkolenia było przekazanie pracownikom szkoły wiadomości na temat najnowszych badań z dziedziny psychologii pozytywnej, a także nauczenie ich korzystania z szeregu umiejętności, które niesie za sobą ten rodzaj psychologii, zarówno w życiu prywatnym, jak i zawodowym. Główne tematy dyskusji to: wzmocnienie odporności na niepowodzenia (resilience), okazywanie wdzięczności (gratitude), sprawniejsza komunikacja międzyludzka oraz optymizm. Dyskutowano także o umiejętności identyfikowania i wykorzystywania zalet sygnaturowych (signature strengths) do pokonywania różnego rodzaju życiowych wyzwań: trudności, niepowodzeń czy nowych sytuacji wymagających od danej osoby ofiary, wysiłku itp. Skupiono się w szczególności na zaznajomieniu nauczycieli i wychowawców z metodami przekazywania uczniom pozytywnych treści, czyli tematów pobudzających optymizm, życzliwość, otwartość na innych. Wykładowcy z Penn zaproponowali w tym przed- 
miocie szczegółowe programy nauczania. Najistotniejsze zasady i umiejętności przedstawiane były w sesjach plenarnych. Nauczanie tychże umiejętności przez ćwiczenia oraz dyskusje na temat ich praktycznego zastosowania w życiu kontynuowano w mniejszych grupach.

Drugim etapem szkolenia pracowników GGS był stały kontakt ze specjalistami z Penn. Podczas gdy kilku wykładowców, m.in. Seligman, pozostali przez rok w GGS, by na bieżąco monitorować przebieg programu i pomagać w jego wdrażaniu, inni specjaliści, jak np. Baumeister, Fowler, Fredrickson, Mosca, Park, Peterson, Post czy Vaillant, byli zapraszani do szkoły na regularne wizyty i prezentacje. Dzięki temu, iż część nauczycieli z GGS została wyszkolona w organizowaniu podobnych kursów dla osób niezaznajomionych $\mathrm{z}$ tematem, wiedza na temat pozytywnej psychologii oraz jej praktycznego zastosowania na poziomie organizacyjnym została sukcesywnie przekazana pozostałym pracownikom szkoły (pracownikom pionu ekonomicznego, kwestury i biura promocji, bibliotekarzom czy też pracownikom nadzoru technicznego, obsługi i zaopatrzenia) (Seligman i in., 2009). Do chwili obecnej 392 pracowników szkoły przeszło wspomniane wyżej szkolenia (Robinson, 2012b).

Rezultatem współpracy GGS z Seligmanem było wypracowanie konceptu określonego mianem ,edukacji pozytywnej”. Terminem tym zdefiniowano tradycyjny system edukacyjny skoncentrowany na zdobywaniu wiedzy i umiejętności, do którego w sposób systematyczny włączana jest zorganizowana promocja dobrostanu jednostki i wspólnoty. Zgodnie z tym holistycznym podejściem dobrostan ucznia oraz jego osiągnięcia akademickie postrzegane są jako jednakowo ważne czynniki umożliwiające pełny rozwój ucznia oraz osiągnięcie sukcesu i satysfakcji na dalszej drodze życiowej. Uznając te pozytywne, naukowo potwierdzone wpływy nauki o dobrostanie na edukację, w 2009 r. GGS utworzyła Departament Edukacji Pozytywnej. Departament ten zajął się opracowaniem modelu nauczania, a także wypracowaniem praktycznych metod przekazywania tej wiedzy i zastosowania nauki w rzeczywistych warunkach życiowych (Meek, 2010).

\section{Wdrażanie edukacji pozytywnej do programu nauczania w GGS}

Współpraca pomiędzy GGS a naukowcami z USA zaowocowała stworzeniem specyficznego programu nauczania edukacji pozytywnej dostosowanego do najróżniejszych aspektów przekazywania wiedzy i uczenia się, począwszy od klasy zerowej, a na klasie maturalnej skończywszy. Od początku 2009 r. Edukacja Pozytywna stała się formalnym przedmiotem dla klas VII, IX i X (uczniowie 
w wieku od 13 do 16 lat). Nauczanie w tychże klasach zostało oparte na programie napisanym przez czołowych naukowców zajmujących się pozytywną psychologią, przy współpracy z doświadczonymi nauczycielami z GGS (GGS, 2010a).

Dla klas VII przyjęto kurs oparty na Penn Resiliency Programme (Gillham, Reivich, Jaycox, Seligman i Silver, 2007) - promujący optymizm przez uczenie bardziej otwartego, realistycznego myślenia, prowadzącego do zwiększenia odporności uczniów na problemy pojawiające się w okresie wczesnego dojrzewania. Rozbudowany przez GGS program kładzie nacisk na związki pomiędzy myślami a emocjami. Uczniowie dowiadują się o różnych stylach myślenia, uczą się, jak unikać pochopnych ocen czy decyzji, w jaki sposób spojrzeć na problemy z innego punktu widzenia oraz radzić sobie z przeciwnościami losu. Kurs omawia podejmowanie decyzji, strategię i wagę obrony własnych poglądów, ale też rozwiązywanie konfliktów czy problemów przez negocjacje. Przekazywane są też w nim umiejętności budowania bogatszych więzi społecznych. Uczniowie zaznajamiani są wreszcie z różnymi metodami relaksacyjnymi oraz poznają typową dla pozytywnej psychologii terminologię (Meek, 2010).

Nieco inny kurs przygotowano dla około 220 uczniów klas IX, którzy w ciągu roku szkolnego przebywają w Timbertop - oddzielnym kampusie położonym w Alpach Australijskich. Obowiązujący w Timbertop specyficzny program nauczania kładzie nacisk na współżycie z otaczającą przyrodą i fauną, na wartości związane z pracą grupową oraz na stawianie czoła różnego rodzaju wyzwaniom, wliczając wymagania fizyczne. Kulminacją programu jest 28-kilometrowy bieg przez góry, do którego uczniowie są indywidualnie przygotowywani przez cały rok, a którego celem jest samo jego ukończenie i w konsekwencji uświadomienie uczniom ich potencjału. Z uwagi na specyfikę tego kampusu podstawowym konceptem nauczania wprowadzonej w Timbertop edukacji pozytywnej jest wzmocnienie odporności na niepowodzenia. W okresie początkowym, dla osiągnięcia tego celu, uczniowie poznają opisany przez Ellisa model ABC (Ellis, 1972; Ellis i Dryden, 1997). Według niego przekonania (B - Belief) o danej przeciwności/zdarzeniu aktywującym (A - Activating event), tj. myśli, doświadczeniu wewnętrznemu albo doświadczeniu pochodzenia zewnętrznego, wpływają na wynikające $\mathrm{z}$ tego konsekwencje ( $\mathrm{C}$ - Consequences $)$, tj. uczucia i emocje. Dzięki ćwiczeniom uczniowie poznają, jak spowolnić ten proces przez bardziej precyzyjne i elastyczne myślenie. Dowiadują się, jak na problem można spojrzeć z innej perspektywy oraz jak przeciwstawić się nadmiernemu generalizowaniu, personalizowaniu czy uzewnętrznianiu przeciwności. Nauczani są real-time resilience (Reivich, Shatte, 2003), tzn. podważania prze- 
konań, które mogą zmienić daną przeciwność w jeszcze poważniejszy problem lub negatywnie wzmocnić jej skutki. Metody te pomagają uczniom w podejmowaniu lepszych, mniej pochopnych decyzji, i to szczególnie w sytuacjach kryzysowych, z którymi dość często muszą się stykać w Timbertop. Oprócz odporności w programie nauczania Timbertop są także wykłady o kapitalizacji/pomnażaniu pozytywnych emocji (active constructive responding) (Gable i in., 2004). Uczniowie zachęcani są do zastosowania teorii w praktyce, m.in. do aktywnej i konstruktywnej reakcji na pozytywną wiadomość otrzymaną od drugiej osoby. Kurs informuje także o utrzymywaniu odpowiedniej proporcji pomiędzy pozytywnymi a negatywnymi doświadczeniami emocjonalnymi. Za przykładem Fredrickson nauczane jest utrzymywanie proporcji 3:1 pomiędzy pozytywnością a negatywnością (Fredrickson, Losada, 2005). Generalnie cały program edukacji pozytywnej w Timbertop ma za zadanie zwiększyć u uczniów umiejętności podejmowania decyzji, radzenia sobie z problemami, korzystania z nowych rozwiązań oraz nawiązywania mocniejszego, głębszego kontaktu z innymi ludźmi. Kurs ma uczyć realistycznego i twórczego myślenia o przeciwnościach, których doświadcza większość uczniów w okresie dojrzewania (GGS, 2010a).

Kurs dla klas X (lekcje odbywają się dwa razy w tygodniu) skupia się na odkrywaniu i wykorzystywaniu osobistych zalet i kompetencji, tzw. zalet sygnaturowych. Na wstępie uczniowie zachęcani są do opisania momentu w swoim życiu, w którym albo czuli się najlepiej, albo osiągnęli największy sukces. Po przeprowadzeniu testu zalet sygnaturowych (VIA Signature Strengths Questionnaire) uczniowie badają treść swoich opisów w celu odnalezienia tych zalet. Inne, podobne temu ćwiczenia, mają za zadanie wypracowanie wspólnego języka do omawiania doświadczeń życiowych pomiędzy uczniami a nauczycielami. Ćwiczenia te to np. przeprowadzanie wywiadów z członkami własnej rodziny w celu stworzenia „drzewa genealogicznego” zalet sygnaturowych, uczenie się, jak używać zalet do pokonywania wyzwań, rozwijanie tych zalet, które, jak wykazał test, nie znalazły się wśród pięciu najsilniejszych, czy wreszcie znalezienie wśród wykładowców i uczniów osób, które najlepiej reprezentują daną zaletę czy kompetencję (Robinson, 2011).

W podobnym tonie zorganizowano ćwiczenia nauczania odporności na przeciwności, postrzegania dobrodziejstw, używania sił psychicznych, zdobywania sensu istnienia, wykorzystywaniu stanu przepływu (flow) oraz pozytywnych emocji. Uczniowie klas X zachęcani są np. do pisania listów z podziękowaniami do swoich rodziców czy opiekunów, delektowania się dobrymi wspomnieniami, przezwyciężania negatywności oraz postrzegania, jakie wartości dla 
dawcy niesie ze sobą okazywanie życzliwości. Ważnym narzędziem w dostrzeganiu pozytywów jest tzw. dziennik dobrodziejstw (blessings journal), w którym każdego wieczora uczniowie mają notować trzy rzeczy czy wydarzenia, które przyniosły im zadowolenie. Mogą być to wydarzenia zarówno dość błahe, np. udzielenie poprawnej odpowiedzi na lekcji czy otrzymanie pozytywnej oceny z danego przedmiotu, jak i bardziej znaczące, np. zadowolenie z rozwiązania personalnego konfliktu z innym uczniem. Szczególny nacisk jest kładziony na refleksję nad tymi zdarzeniami. Uczniowie mają również za zadanie rozważenie jednego z następujących zagadnień: „Dlaczego dane dobre wydarzenie/ /rzecz w ogóle miało miejsce?”, „Co to dla mnie oznacza?”, „W jaki sposób mogę zwiększyć prawdopodobieństwo, że w przyszłości będą mi się zdarzać częściej pozytywne doświadczenia?”.

Oprócz formalnych programów nauczania, takich jak te przedstawione powyżej, edukacja pozytywna jest też wdrażana do najróżniejszych kursów dydaktycznych i wychowawczych w GGS. Wiedza stosowana jest zarówno w poszczególnych przedmiotach - muzyce, literaturze, geografii czy sztukach plastycznych - jak i w sporcie. Elementy edukacji pozytywnej są też częścią pracy duszpasterskiej i programu wychowawczego opartego na systemie małych grup działających wewnątrz internatów (tutorial groups), a także w indywidualnym podejściu do ucznia.

Podczas gdy wcześniej dziesięcio-dwunastoosobowe grupy uczniów spotykające się raz w tygodniu ze swoim wychowawcą miały na celu głównie wymianę informacji, pomoc dydaktyczną oraz budowanie lepszych kontaktów między uczniami różnych poziomów w danym internacie, od 2010 r. grupy te stały się znaczącym narzędziem do przekazywania treści pozytywnych i dyskutowania nad nimi. Ustanowiony został dla nich specjalny program, który koncentruje się na rozmaitych formach dobrostanu. W grupach, w sposób mniej formalny, omawiane są zarówno kluczowe koncepty związane z edukacją pozytywną, tj. zalety sygnaturowe, odporność na niepowodzenia, sposoby na kapitalizację pozytywnych emocji czy różnice między negatywnym a pozytywnym nastawieniem (fixed vs open mindset), jak i tematy związane z bardziej ogólnym zrozumieniem dobrostanu. Omawiane są m.in. związki pomiędzy zdrowiem psychicznym a zdrowiem fizycznym. Tematami są też dobre odżywianie, sen i odpoczynek, umiejętności dobrego przygotowywania się do zajęć czy egzaminów (study skills), budowanie kontaktów z innymi (relationships), tworzenie efektywnej organizacji (team-building) czy wreszcie postawy i obowiązki wynikające z przewodzenia innymi (leadership) (Meek, 2011b). 
Te i inne przykłady mają też wpływ na aplikację edukacji pozytywnej w codziennym życiu (living positive education). Pojawiają się one m.in. w pracy duszpasterskiej. Biblijne fragmenty dotyczące odwagi, przebaczania, trwałości i wytrzymałości przedstawiane podczas nabożeństw (uczniowie spotykają się w szkolnej kaplicy dwa razy w tygodniu: raz w dzień powszedni i raz w niedzielę) wzmacniają dyskusje w klasach, i odwrotnie - rozmowy w klasach pomagają bardziej zrozumieć czytania biblijne. Gdy np. wdzięczność była tematem klasowych dyskusji wśród uczniów klas dziesiątych, ten sam temat pojawił się równocześnie w czytaniach biblijnych i na kazaniu tego tygodnia (Seligman $\mathrm{i}$ in., 2009).

Organizowane są również różnorodne warsztaty dla specyficznych grup wiekowych. Klasy VIII biorą np. udział w jednodniowym szkoleniu, którego celem jest praca zespołowa i formowanie lepszych kontaktów z rówieśnikami (GGS, 2010b). Z kolei uczniowie klas XI, przygotowując się do przejęcia obowiązków po odchodzących ze szkoły uczniach klas XII, uczestniczą w dwudniowym kursie przewodzenia. Przez szereg gier, zabaw i dyskusji pogłębiają wiedzę na temat pracy zespołowej, planowania, a nade wszystko wymagań i obowiązków oczekujących przyszłych liderów. W tym samym czasie uczniowie klas maturalnych uczestniczą w sesjach informacyjnych mających pomóc im w lepszym przygotowaniu się do egzaminów końcowych. Tematami dyskusji są m.in. opóźniona gratyfikacja, samokontrola, zapobieganie prokrastynacji, pozytywne nastawienie oraz zastosowanie ćwiczeń medytacyjnych związanych z praktykowaniem mindfulness dla polepszenia koncentracji i zapanowania nad przedegzaminacyjnymi nerwami (GGS, 2010b).

Według przeprowadzonych przez szkołę wstępnych ocen wprowadzenie edukacji pozytywnej do życia codziennego przekłada się na lepsze kontakty pomiędzy uczniami i nauczycielami oraz na skuteczniejsze rozwiązywanie konfliktów pomiędzy uczniami. Natomiast posiadanie wspólnego języka opartego na zaletach sygnaturowych poprawiło komunikację. Społeczność GGS wydaje się być bardziej zwarta i otwarta na innych. Uczniowie częściej niż poprzednio angażują się w najróżniejsze akcje charytatywne. Przeprowadzają zbiórki pieniężne na cele dobroczynne, aktywnie biorą udział w działalności charytatywno-opiekuńczej, oświatowej i wychowawczej (Williams, 2011).

Wstępne badania pokazują też, że program ma duże poparcie wśród uczniów. Na podstawie przeprowadzonego w 2012 r. sondażu wśród klas dziesiątych 66\% uczniów zadeklarowało, że edukacja pozytywna zmieniła sposób, w jakim postrzegają siebie i innych, 74\% zgodziło się ze stwierdzeniem, że przedmiot ten powinien być obowiązkowy w klasie X, a 87\% stwierdziło, że bardzo cenne 
byłoby przekazanie wiedzy, którą sami doświadczyli, kolegom spoza szkoły i własnej rodzinie (Robinson, 2012b).

\section{Dyskusja}

Jak zdają się pokazywać wyżej wymienione przykłady, wypracowany w GGS model edukacji pozytywnej tworzy elastyczne ramy, które ułatwiają planowanie, wdrażanie i ewaluację aplikacji pozytywnej psychologii, m.in. wzrost wiedzy i umiejętności z niej wynikających w warunkach szkolnych. Elastyczność zdaje się bardzo ważną zaletą tego modelu, gdyż pozwala na jego ulepszanie wprowadzanie lepszej metodologii, łączenie nowych konceptów i rozbudowywanie istniejących programów. Na przełomie 2011/2012 r. centralnym elementem modelu stał się koncept „rozkwitu” czy - jak to jest niekiedy określane w polskiej literaturze z zakresu pozytywnej psychologii - idea „prosperowania” (flourishing), która jest rozumiana jako połączenie zadowolenia z własnego życia $\mathrm{z}$ aktem czynienia dobra przysparzającego światu wartości. Według jego autorów pełne zadowolenie z życia składa się z szeregu emocji i doświadczeń, takich jak uczucie satysfakcji z wydarzeń z przeszłości, zadowolenia ze stanu obecnego i nadziei na przyszłość (Robinson, 2012a). Koncept obejmuje również siły charakteru i odporność na negatywne emocje i niepowodzenia. Czynienie dobra jest natomiast konceptem dobrostanu rozumianego przez pryzmat eudajmonii, która to idea ma dać uczniom i ich nauczycielom wiedzę i umiejętności niezbędne do stawiania czoła przeszkodom oraz podejmowania wyzwań. Idea wymaga przekroczenia granic egoizmu i skoncentrowania się na czynieniu dobra, robieniu każdego dnia czegoś wartościowego ze swoim życiem, z pożytkiem dla danej społeczności czy wręcz ogółu ludzkości.

Uznanie „prosperowania”, tj. stworzenia warunków dla rozkwitu całej społeczności szkolnej: uczniów, nauczycieli, personelu administracyjnego (non-teaching staff), alumnów oraz rodziców, za główny cel edukacji pozytywnej w GGS zaowocowało dalszym sprecyzowaniem modelu. Wydany w 2012 r. oficjalny dokument opisujący cele i metody nauczania edukacji pozytywnej w GGS przedstawia ten model jako składający się z sześciu powiązanych ze sobą sfer nauczania, kluczowych dla stworzenia warunków rozkwitu (zob. rys. 1). 
Rysunek 1. Wielowymiarowy model edukacji pozytywnej w GGS

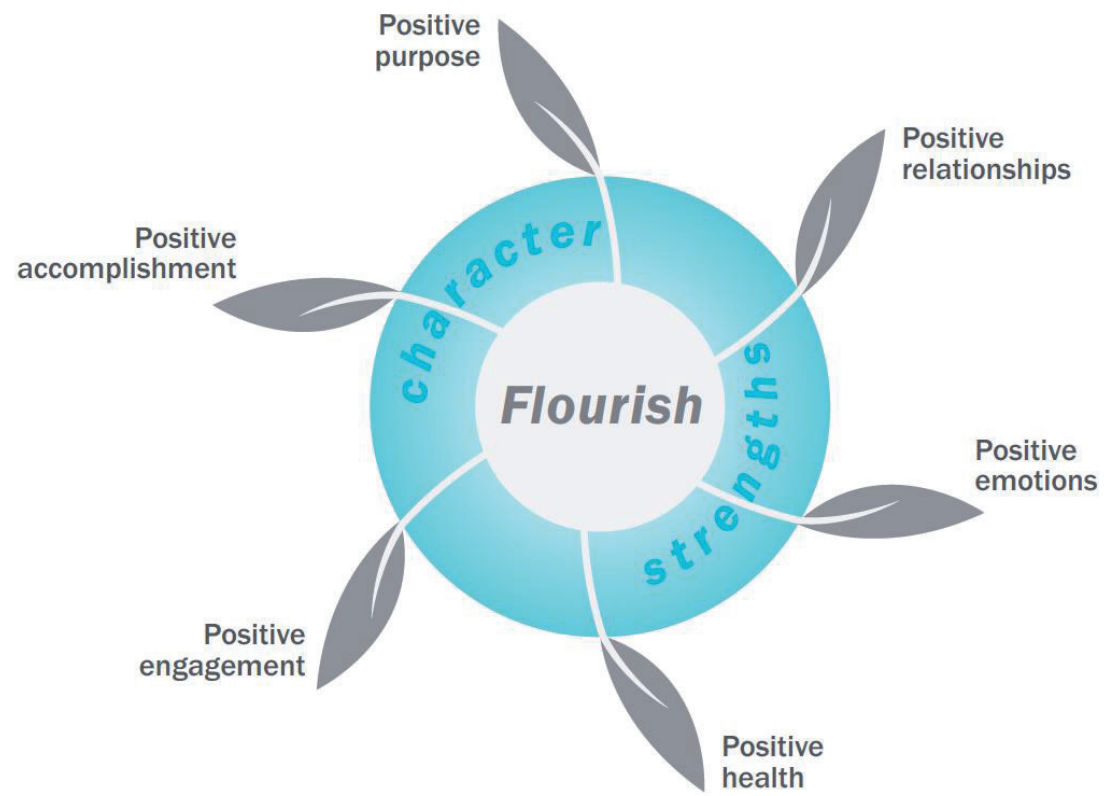

Pierwsza sfera - pozytywne zależności (positive relationships) - obejmuje cały wachlarz spraw i umiejętności związanych z komunikacją międzyludzką, nawiązywaniem kontaktów z innymi oraz rozwojem emocjonalnym. Kluczowe pojęcia dla tej sfery to: umiejętności towarzyskie (social intelligence), komunikacja, przebaczanie i praca zespołowa.

Sfera druga - pozytywne emocje (positive emotion) - ma za zadanie nie tylko pomóc uczniom przewidywać, rozpoczynać, doświadczać, przedłużać i budować pozytywne emocje, ale również właściwie reagować na emocje negatywne. Główne definicje dla tej domeny to: satysfakcja i delektowanie się uczuciami, utrzymywanie odpowiednich proporcji pomiędzy pozytywnymi a negatywnymi doświadczeniami emocjonalnymi.

Sfera trzecia - pozytywne zaangażowanie (positive engagement) - ma rozwijać w uczniach umiejętności związane ze zrozumieniem i doświadczaniem całkowitego zaangażowania się w daną czynność czy funkcję i bada wpływ takiego zaangażowania się na indywidualny dobrostan. Kluczowe pojęcia charakteryzujące sferę to: stan pochłonięcia, teoria motywacji, zalety sygnaturowe oraz odkrywanie własnych zainteresowań i pasji. 
Kolejna sfera - pozytywne osiągnięcia (positive accomplishment) - koncentruje się na rozwijaniu indywidualnego potencjału przez urzeczywistnienie osobistych dążeń i obejmuje następujące definicje: pozytywne nastawienie, życiowe cele, a także rolę pochwały oraz teorię nadziei.

Pozytywne zdrowie (positive health) jest sferą koncentrującą się na promocji dobrych nawyków dla osiągnięcia oraz utrzymania jak najlepszego zdrowia fizycznego i psychicznego. Kluczowe pojęcia dla tej sfery to: dbałość, odporność na niepowodzenia i zdrowie fizyczne.

Szósta i ostatnia sfera - pozytywne cele (positive purpose) - obejmuje zrozumienie, wiarę i zaangażowanie $\mathrm{w}$ wartościowe plany i zadania, celową pracę na rzecz innych. Główne pojęcia tej sfery to: sens i cel życia, świadomość społeczna i społeczna praca.

Wszystkie powyższe sfery są oparte na zaletach sygnaturalych, które wiążą w całość model wypracowany przez GGS oraz tworzą wspólny język pomiędzy uczniami i nauczycielami dla omawiania wymienionych wyżej doświadczeń (A Model for Positive Education, 2012). Mimo definitywnych osiągnięć model GGS jest w toku rozwoju. Jednym z największych wyzwań twórców programu jest stworzenie systemu do realnej oceny jego sukcesu, zarówno na poziomie poszczególnych uczniów, jak i całej instytucji. W chwili obecnej GGS mierzy na przykład ,,prosperowanie”, używając do tego kwestionariusza (Individual Flourishing Questionnaire) sporządzonego dla szkoły przez Huppert i So z Wellbeing Institute na Uniwersytecie w Cambridge. Kwestionariusz mierzy m.in. pozytywne emocje, zaangażowanie i zainteresowania, sens i cel życia, pozytywne relacje interpersonalne, odporność na niepowodzenia, optymizm, witalność, spokój ducha i pewność siebie (Huppert, So, 2010). Pozostaje jednak pytanie: czy kiedykolwiek będzie możliwe zebranie i przeanalizowanie informacji na temat długotrwałych skutków włączenia edukacji pozytywnej do programu nauczania? Czy i w jaki sposób mierzyć postęp nauki indywidualnych uczniów? W jaki sposób taki postęp oceniać? Czy i jak udowodnić wpływ edukacji pozytywnej na osiągnięcia akademickie czy sportowe?

Znalezienie odpowiedzi na te i inne pytania to obecnie jeden z priorytetów GGS. W ostatnim okresie szkoła nawiązała współpracę z Monash University w Melbourne. Wraz z naukowcami z tego uniwersytetu GGS wystąpiła do Australian Research Council o pomoc w sfinansowaniu badań długoterminowych. Celem projektu pod nazwą „Adolescent experiences of a Positive Education program: A comprehensive and innovative approach to evaluating program outcomes" jest wypracowanie kompleksowych, nowatorskich i naukowo potwier- 
dzonych technik oceny efektów stworzonego przez GGS programu (Robinson, 2012b).

Autorzy modelu zastanawiają się również, jak zbalansować program, tak by nie był on nadmiernym ciężarem dla grona pedagogicznego. Szkolenie nauczycieli, a później przygotowanie się przez nich do konkretnych lekcji i prowadzenie specyficznych zajęć wymaga bowiem dodatkowego czasu w bardzo już napiętym programie dydaktycznym. Podejmowane są też inicjatywy spisania doświadczeń szkoły w celu przekazania programu innym instytucjom pedagogicznym oraz placówkom naukowym.

Jako instytucja, która całościowo przyjęła idee nurtu psychologii pozytywnej do własnej struktury instytucjonalnej, GGS jest całkowicie oddana dalszemu usprawnianiu programu. Jak wyjaśnia dyrektor szkoły, Meek, „Celem GGS jest edukacja, która ma moc przekształcić doświadczenie świata przez dziecko". Według niego ,posiadanie wiary we własne możliwości, zrozumienie różnorodności, akceptacja różnego rodzaju wyzwań, mądre działanie oraz odporność na niepowodzenia są niezbędnymi składnikami zdrowego umysłu, ciała i ducha. Od samego początku zamierzaliśmy uhonorować integralność naszych uczniów poprzez stworzenie im warunków, by wyrośli na silnych ludzi. Edukacja pozytywna jest częścią składową naszego programu, albowiem jesteśmy przekonani, że głębokie, pełne wartości życie jest niezbędne do szczęścia i utrzymania równowagi poprzez całą drogę życiową" (Meek, 2011a, s. 1).

\section{Zakończenie}

Psychologia pozytywna jest stosunkowo młodym nurtem myśli i wciąż podlega znaczącym przemianom. Przykładem tego może być choćby redefiniowanie przedmiotu studiów, czyli przejście od terminu happiness (szczęście) w stronę pojęć flourishing (prosperowanie) czy well-being (dobrostan), które to mają bardziej poważne konotacje naukowe (Seligman, 2011). Jako nurt prężnie rozwijający się stoi przed wieloma wyzwaniami. $Z$ jednej strony czysto naukowymi (Gulla, Tucholska, 2007), z drugiej zaś przed celami natury praktycznej, czyli jak przeszczepić odkrycia naukowe do konkretnego środowiska. Wciąż pozostaje wiele kontrowersji wokół przedmiotu psychologii pozytywnej oraz sposobu, w jaki podejmuje zagadnienia (Taylor, 2001; Resnick i in., 2001; Held, 2004; Lazarus, 2003; McDonald, O'Callaghan, 2008; Trzebińska, 2008).

Niewątpliwie jeszcze daleka droga do pełnej klaryfikacji pojęć związanych z dobrostanem i szczęściem człowieka na poziomie teoretycznym. Ponadto sposób aplikacji psychologii pozytywnej w edukacji nie jest czymś jednowy- 
miarowym, a prawdziwa weryfikacja doświadczenia GGS wiąże się nie tylko z czasem, ale i poszukiwaniem nowatorskich metod pomiaru i mierzenia progresu. Jednak niewątpliwie GGS wyruszyła w tę długą naukową drogę i zdobywa pierwsze cenne doświadczenia, które mogą być bardzo pomocne dla innych, chcących korzystać z bogatego doświadczenia pionierów.

\section{Bibliografia}

Cameron K. (2008), Positive Leadership: Strategies for Extraordinary Performance, Berrett-Koehler, San Francisco.

Conoley C. D., Conoley J. C. (2009), Positive Psychology and Family Therapy. Creative Techniques and Practical Tools for Guiding Change and Enhancing Growth, Wiley, New Jersey.

Czapiński J. (2004), Psychologia pozytywna. Nauka o szczęściu, zdrowiu, sile i cnotach człowieka, Wydawnictwo Naukowe PWN, Warszawa.

Dewey J. (1897), My Pedagogic Creed, „School Journal”, No. 54 (3), s. 77-80.

Dewey J. (1938), Experience and education, Kappa Delta Pi, New York, DOI: http://dx.doi. org/10.1080/00131728609335764.

Donaldson S. I., Ko I. (2010), Positive organizational psychology, behavior, and scholarship: A review of the emerging literature and evidence base, ,Journal of Positive Psychology", No. 5, s. 171-199, DOI: http://dx.doi.org/10.1080/17439761003790930.

Duckworth A. L., Steen T. A., Seligman M. E. P. (2005), Positive psychology in clinical practice, „Annual Review of Clinical Psychology”, No. 1, s. 629-651.

Ellis A. (1972), The a-b-c's of rational-emotive therapy, Institute for Rational Living, New York.

Ellis A., Dryden W. (1997), The practice of rational emotive behavior therapy. Second edition, Springer, New York.

Gable E. L., Reis H. T., Impett E. A., Asher E. R. (2004), What do you do when things go right? The intrapersonal and interpersonal benefits of sharing positive events, „Journal of Personality and Social Psychology", No. 87, s. 228-245, DOI: http://dx.doi. org/10.1037/0022-3514.87.2.228.

Gable S. L., Haidt J. (2005), What (and why) is positive psychology?, „Review of General Psychology", No. 9, s. 103-110, DOI: http://dx.doi.org/10.1037/1089-2680.9.2.103.

Geelong Grammar School (2010a), Positive Education: An approach to Teaching, Learning and Living [maszynopis].

Geelong Grammar School (2010b), Positive Education in Action, „Light Blue”, No. 84. 
Gillham J., Reivich K., Jaycox L. H., Seligman M. E. P., Silver T. (2007), Penn Resiliency Programme: the Manual for Teachers [maszynopis].

Gulla B., Tucholska K. (2007), Psychologia pozytywna: cele naukowo-badawcze i aplikacyjne oraz sposób ich realizacji, „Studia z Psychologii w KUL”, nr 14, s. 133-152.

Fredrickson B. L., Losada M. F. (2005), Positive affect and the complex dynamics of human flourishing, „American Psychologist”, No. 60, s. 678-686, DOI: http://dx.doi. org/10.1037/0003-066X.60.7.678.

Harris R. (2008), The Happiness Trap: How to stop struggling and start living, Trumpeter, Boston, MA.

Held B. S. (2004), The negative side of positive psychology, „, Journal of Humanistic Psychology", No. 44, s. 9-46, DOI: http://dx.doi.org/10.1177/0022167803259645.

Huppert F. A., So T. T. C. (2010), Individual Flourishing Questionnaire-Short version (IFQ-Short) prepared for Geelong Grammar School, University of Cambridge, Cambridge.

Kulik R. (2010), W zgodzie z samym soba, innymi i światem - kluczowe kompetencje w edukacji integralnej, w: Kulik R., Kukowka I., Zrozumieć siebie na nowo. 10 zasad jak uczyć o przyrodzie by poszerzać swoje mate Ja, „Zeszyty Ekologiczne”, nr 2, s. 5-53.

Kwiatek P. (2011), Sprawozdanie z konferencji naukowej zorganizowanej przez ośrodek edukacyjny w Geelong Grammar School, Australia: Wiara i psychologia pozytywna, 27 lipca 2010, Geelong - Australia, „Seminare”, nr 30, s. 302-304.

Kwiatek P. (2012), Sprawozdanie: II Międzynarodowy Kongres Psychologii Pozytywnej zorganizowanej przez Międzynarodowe Stowarzyszenie Psychologii Pozytywnej, 23-26 lipca 2011, Filadelpfia-USA, „Seminare”, nr 31, s. 317-319.

Lazarus R. S. (2003), Does the positive psychology movement have legs?, „Psychological Inquiry”, No. 14, s. 93-109, DOI: http://dx.doi.org/10.1207/S15327965PLI1402_02.

Linley P. A., Joseph S. (2004), Applied positive psychology: A new perspective for professional practice, Wiley, Hoboken, DOI: http://dx.doi.org/10.1002/9780470939338.ch1.

Lyubomirsky S. (2008), The how of happiness: A scientific approach to getting the life you want, Penguin Press, New York.

Magyar-Moe J. L. (2009), Therapist's Guide To Positive Psychological Interventions, Academic Press, London.

Meek S. (2010), Principal's Report for Speech Day 2010, „Geelong Grammar School Speech Day: Sunday 24 October 2010", Corio: GGS, s. 5-31.

Meek S. (2011a), A Postive Future, w: Geelong Grammar School (Prospectus), Corio: GGS.

Meek S. (2011b). Principal's Report: Speech Day 2011, Corio: GGS. 


\section{DONIESIENIA Z PRAKTYKI EDUKACYJNEJ}

McDonald M., O'Callaghan J. (2008), Positive Psychology: A Foucauldian critique, „The Humanistic Psychologist”, No. 36, s. 127-142, DOI: http://dx.doi. org/10.1080/08873260802111119.

McHenr L. (2009), Science and the Pursuit of Wisdom: Studies in the Philosophy of Nicholas Maxwell, Ontos Verlag, Frankfurt.

Montessori M. (1949), The Absorbent Mind, Henry Holt and Company, New York.

Myers D. G. (2000), The American paradox: Spiritual hunger in an age of plenty, Yale University Press, New Haven.

Peterson C., Seligman M. E. P. (2004), Character Strengths and Virtues: A Handbook and Classification, Oxford University Press, New York.

Reivich K., Shatte A. (2003), The Resilience Factor: 7 Keys to Finding Your Inner Strength and Overcoming Life's Hurdles, Crown Publishing Group, New York.

Resnick S., Warmoth A., Serlin I. A. (2001), The humanistic psychology and positive psychology connection: Implications for psychotherapy, ,Journal of Humanistic Psychology", No. 41, s. 73-102, DOI: http://dx.doi.org/10.1177/0022167801411006.

Robinson J. (2011), A Positive Community, „Light Blue”, No. 83, s. 10-11.

Robinson J. (2012a), A Model for Positive Education, „Light Blue”, No. 86, s. 12-13.

Robinson J. (2012b), Positive Education at GGS: The Way Forward 2012-2015, [maszynopis].

Rousseau J. J. (1979), Emile, or On Education (Tr. Allan Bloom), Basic Books, New York.

Sander T. (2011), Positive Computing, w: Biswas-Diener R. (red.), Positive Psychology as Social Change, Springer, London, s. 309-324, DOI: http://dx.doi.org/10.1007/978-90481-9938-9_17.

Seligman M. E. P. (2005), Prawdziwe szczęście. Psychologia pozytywna a urzeczywistnienie naszych możliwości trwałego spetnienia, Media Rodzina, Poznań.

Seligman M. E. P. (2008), Positive Education and the new prosperity: Australia's edge, „Education Today”, No. 8 (3), s. 20-21.

Seligman M. E. P. (2011), Flourish: A Visionary New Understanding of Happiness and Wellbeing, Free Press, New York.

Seligman M. E. P., Ciskszentmihalyi M. (2000), Positive Psychology: An Introduction, „American Psychologist”, No. 55, s. 5-14, DOI: http://dx.doi.org/10.1037//0003066X.55.1.5.

Seligman M. E. P., Parks A. C., Steen T. (2006), A balanced psychology and a full life, w: Huppert F., Keverne B., Baylis N. (red.), The science of well-being, Oxford University Press, Oxford, s. 275-283, DOI: http://dx.doi.org/10.1093/acprof:o so/9780198567523.003.0010. 
Seligman M. E. P., Ernst R., Gillham K., Linkins M. (2009), Positive Education: positive psychology and classroom interventions, „Oxford Review of Education”, No. 35 (3), s. 293-311, DOI: http://dx.doi.org/10.1080/03054980902934563.

Sharma M., Atri A., Branscum P. (2013), Foundations of mental health promotion, Jones and Bartlett, Sudbury, MA.

Sheldon K. M., King L. (2001), Why positive psychology is necessary, „American Psychologist", No. 56, s. 216-217, DOI: http://dx.doi.org/10.1037//0003-066X.56.3.216.

Taylor E. (2001), Positive psychology and humanistic psychology: A reply to Seligman, „Journal of Humanistic Psychology”, No. 41, s. 13-29, DOI: http://dx.doi. org/10.1177/0022167801411003.

Terjesen M. D., Jacofsky M. D., Froh J. J., DiGiuseppe R. A. (2004), Integrating positive psychology into schools: Implications for practice, „Psychology in the Schools”, No. 41, s. 163-172, DOI: http://dx.doi.org/10.1002/pits.10148.

Trzebińska E. (2008), Psychologia pozytywna, Wydawnictwo Akademickie i Profesjonalne, Warszawa.

Watson D. (2010), The Question of Morale: managing happiness and unhappiness in university life. McGraw-Hill: Open University Press.

Williams P. (2011), Pathways to Positive Education at Geelong Grammar School: Integrating Positive Psychology and Apreciative Inquiry, ,AI Practitioner”, No. 13 (2), s. 8-14.

\section{Application of positive psychology in education based on experience of Geelong Grammar School (Australia)}

\section{Summary}

The article examines the implementation of positive psychology in education on the example of Geelong Grammar School (GGS) in Australia. The project deserves special attention as GGS is the first educational institutions in the world to integrate the key tenets of positive psychology into its curriculum. The school is using implicit and explicit teaching of positive psychology skills and principles across all year levels, that is from ELC to year 12, and across all aspects of school life: academic subjects, pastoral life, sport and the co-curriculum programme. The article consists of two parts. The first is a theoretical introduction to selected issues related to positive psychology and education, while the second part provides a case study of how this works in practice at GGS.

Keywords: Greelong Grammar School, positive psychology, education. 